\title{
Analytical Study of Thermomechanical Strength of Assemblies with Optional Plane Flanges. The Effect of the Flange Ring Rotation Around the Median Circumference
}

\section{RADU I. IATAN, GEORGETA ROMAN (URSE) ${ }^{1 *}$, GHEORGHITA TOMESCU, ANGELA CHELU ${ }^{1}$}

Politehnica University of Bucharest, Industrial Process Equipment Department, 313 Splaiul Independentei, 060042, Bucharest, Romania

\begin{abstract}
This paper describes the analytical evaluation of the thermo - mechanical stresses developed in the circular flange assemblies, of optional type, welded to the cylindrical shell of a pressure vessel. In this case, the structure is formed by welding the cylindrical shell on the inner circumference of the flange ring. Based on the theory of deformation compatibility (radial displacements and rotations), the expressions for the evaluation of radial unitary bending moments and the unitary shear forces are deduced. Subsequently, stress values can be calculated and their concentration can be evaluated along the cylindrical shell, below the separation plane of the flange ring.
\end{abstract}

Keywords: circular plate flanges assemblies, stresses, deformations

\section{Introduction}

The sealing of industrial mechanical equipment, dynamic [1-3] or static [4-10], is an extremely important area in ensuring normal and safe operation, known for, the extremely difficult conditions in some concrete situations with high values of working parameters (pressures, temperatures), but also the chemical and / or erosive aggressiveness of processed media. One should not neglect the idea of producing large equipment, which also entails economic considerations, in this case "slimming cures", within acceptable technical limits (i.e. the reduction of the values of their own metal masses, with advantages both for manufacturing, transportation or installation, respectively at the ground loading and wind loads and earthquakes). It is therefore necessary to improve the calculation methods.

The assembling itself must ensure the sealing of the components subassemblies with the essential condition that the material used for sealing is not destroyed, correlated with the quality of the sealed surfaces [9]. The wide variety of flange forms are grouped according to different criteria, regarding the shape of the flange ring, its cross-section and sealing surface configuration, at the same time correlated with the manufacturing technology, the processing environment, require differential analysis of analytical calculation or / and numeric [11-28].

It is mentioned that the study can be made taking into account static and / or dynamic loads, simple or combined (pressures, temperatures, transient regime, fatigue, creep, seismicity) [9,17,29-36], as well as corrosive and / or erosive aggression for metallic or non-metallic (polymer or composites) materials [37]. An essential role in confirming the supporting capacity of flange assemblies is the experimental works to determine strength, rigidity and tightness [38-54].

Mathematical expressions clearly show the influence of the rigidity of the assembly on the seals, so, as much as possible, it is necessary for the diametric dimension of the ring flange to be small as possible, simultaneous with the increase of its thickness, but also with the number of tightening bolts. All of the aforementioned elements simultaneously aim at ensuring safe operation under specific

*email: ursegeanina@yahoo.com 
conditions but also the existence of a minimum consumption of construction material, in this case a lower price of the building material but also of the labour costs and the maintenance [55].

Study assumptions

In the following analytical study the next simplifying assumptions are considered:

1. The construction of flat ring flanges fixed by cylindrical shell welding is accepted (Figure 1); the shell has the same thickness over its entire length;

2. The material of the assembling components is solicited in the elastic field, with overlapping effects of external loads (pressure and temperature), which are accepted with static values.

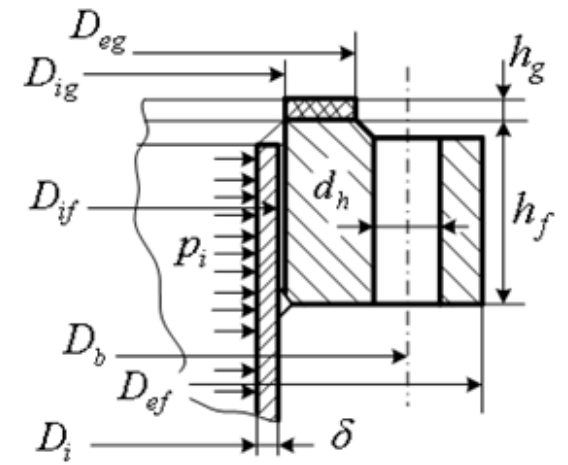

Figure 1. Circular flange

plates (dimensional characteristics schematic)

3.The assembly is decomposed into the composing elements (Fig. 2) so as to determine the deformations caused by the external loads (radial displacements and rotation) and to use their compatibility; between the structural elements of the assembly the bending unit moments $\left(\mathrm{M}_{01}, \mathrm{M}_{02}\right.$, $\left.\mathrm{M}_{03}\right)$ and the unitary shear forces $\left(\mathrm{Q}_{01}, \mathrm{Q}_{02}, \mathrm{Q}_{03}\right)$ (Figure 2) are introduced.

4. The cylindrical shell adjacent to the flange ring, over its entire thickness, is considered to be of length $h_{c}<l_{s c} \approx 1.77 \cdot \sqrt{D_{m c} \cdot \delta}$ so that the theory of short structural elements is used.

5. The existence and effect of the welding for fixing between the cylindrical shell 1 and the flange ring are neglected (Figure 1, Figure 2).

6 . The rotation of the flange ring under the external load is accepted around the mass center of its radial cross section (point B - Fig. 2) [21-26, 56-58].

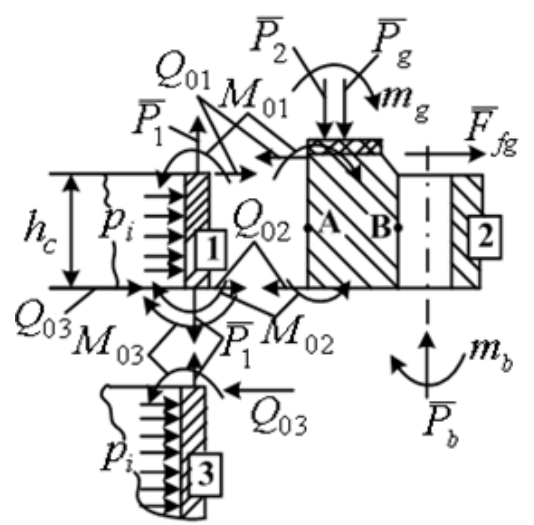

Figure 2. Flange assembly elements decomposition (sketch): 1 - the cylindrical shell adjacent to the flange ring; 2 -the flange ring; 3 - cylindrical shell

7. On the flange ring we also consider the bending unit moments produced by bolts tendency to bend, $m_{b}$ (Fig 2), the eccentric compression of the gasket for sealing, $m_{g}$ (Fig. 2) $[21,22,28,59]$ and the unitary frictional force between the seal and the flange ring, their expression being incorporated in the factor $k_{g b}$ [21,22,24-26,28,59]; from the expression of continuity of deformations, it is ascertained that the effects of the above mentioned loads, lead to the decrease of the total rotation of the flange ring, favoring the tightness of the assembly; in the structure of the $k_{g b}$ factor, the $c_{\vartheta}^{g}, c_{\vartheta}^{b}, c_{\vartheta}^{f g}$ selection factors 
are introduced facilitating the easy notice of the influences of the "resistant" characteristics to the deformation of the flange ring.

Analytical study. Connecting loads

By writing the equations of the deformation compatibility between pairs of elements $1-2$ and $1-3$ (Fig. 2) we arrive at the determined algebraic system written in the form:

$$
[A] \cdot\left\{S_{l}\right\}=\left\{T_{l}\right\},
$$

where:

$$
[A]=\left[\begin{array}{cccc}
a_{11} & a_{12} & \ldots & a_{16} \\
a_{21} & a_{22} & \ldots & a_{26} \\
\ldots & \ldots & \ldots & \ldots \\
a_{61} & a_{62} & \ldots & a_{66}
\end{array}\right],
$$

represents the matrix of influence factors $a_{i j}(i=1 \ldots 6 ; j=1 \ldots 6)$; the transposed vector of connecting loads:

$$
\left\{S_{l}\right\}=\left\{\begin{array}{llllll}
Q_{01} & M_{01} & Q_{02} & M_{02} & Q_{03} & M_{03}
\end{array}\right\}^{T} ;
$$

the transposed vector of free terms (displacements and rotations of external loads - pressure, temperature):

$$
\left\{T_{l}\right\}=\left\{\begin{array}{llll}
b_{1} & b_{2} & \ldots & b_{6}
\end{array}\right\}^{T} .
$$

Expressions of the above terms are indicated in the Appendix

From equality (1) we deduce how to evaluate the unknown values of the present problem - unitary shear forces $Q_{0 \mathrm{k}}(k=1 \ldots 3)$ and bending moments $M_{0 \mathrm{k}}(k=1 \ldots 3)$ - written as:

$$
\left\{S_{l}\right\}=[A]^{-1} \cdot\left\{T_{l}\right\},
$$

where $[A]^{-1}$ represents the inverse of the matrix $[A]$, whose determinant is different from zero.

\section{Rotation of flange ring}

On the basis of the previous relations, establishing the expressions of the connecting loads between the elements of the considered assembly, hypothetically separated (Figure 2), it is possible to deduce the expression of the flange ring rotation. The methodology followed is described in detail in papers $[21,24-$ 26]. In this sense, the connection between the bending unitary moments created by bending bolts and the eccentric compression of the sealing gasket is made. After introducing the effect of the engaging loads acting instantaneously on the flange ring and separating the terms, we get to the calculation relation for the rotation, which is written as:

$$
\vartheta_{f}=\frac{1}{k_{g b}} \cdot f\left(Q_{01}, M_{01}, Q_{02}, M_{02}, \bar{P}_{2}, \bar{P}_{b}, \bar{P}_{g}\right),
$$

where the following function appears:

$$
f\left(Q_{01}, M_{01}, Q_{02}, M_{02}, \bar{P}_{2}, \bar{P}_{b}, \bar{P}_{g}\right),
$$

dependent on the connecting loads and the external loads acting on the flange ring (Appendix).

The maximum value of the flange ring rotation is calculated by:

$$
\left(\vartheta_{f}\right)_{\max }=f\left(Q_{01}, M_{01}, Q_{02}, M_{02}, \bar{P}_{2}, \bar{P}_{b}, \bar{P}_{g}\right) /\left(k_{g b}\right)_{\min },
$$

while the expression for evaluating the minimum rotation value has the form:

$$
\left(\vartheta_{f}\right)_{\min }=f\left(Q_{01}, M_{01}, Q_{02}, M_{02}, \bar{P}_{2}, \bar{P}_{b}, \bar{P}_{g}\right) /\left(k_{g b}\right)_{\max } \text {, }
$$

in which:

$$
\left(k_{g b}\right)_{\min }=\left\lfloor E_{f} \cdot h_{f}^{3} \cdot \ln \left(D_{e f} / D_{i f}\right)\right\rfloor /\left(6 \cdot D_{m g}\right)
$$




$$
\begin{aligned}
& \left(k_{g b}\right)_{\max }=\frac{E_{f} \cdot h_{f}^{3} \cdot \ln \left(D_{e f} / D_{i f}\right)}{6 \cdot D_{m g}}+\frac{D_{m g}}{D_{m f}} \cdot \frac{E_{g} \cdot c_{g}^{3} \cdot\left(D_{e g}-D_{i g}\right)^{3}}{48 \cdot h_{g}}+ \\
& +\frac{D_{b}}{D_{m f}} \cdot \frac{E_{b} \cdot n_{b} \cdot d_{b}^{4} \cdot k_{\vartheta}^{5}}{16 \cdot l_{b} \cdot D_{b}}
\end{aligned}
$$

State of stress in the cylindrical shell

Both the theoretical and experimental works indicate that the stress state is more intense along the length of the cylindrical shell 3 (Figure 2) below the flange - cylindrical shell joint.

Considering the above methodology, after evaluating the $Q_{03}$ unitary shear force and the $M_{03}$ bending unitary moment, the meanings of those loads can be corrected in a new scheme if needed.

We proceed to calculate the bending unitary moment $M_{\mathrm{c}}(x)$, establishing the stretched and compressed fibbers of the cylindrical shell. Through appropriate analysis the distance and the surface with the maximum equivalent stress (dependent on the current $x$, measured along the cylindrical shell 3 ), is determined, using, for example, the von Misses criterion and compares with the allowable design stress. If the resistance condition is passed, the analytical study is completed.

Otherwise, the geometry of the assembly is resized to confirm the technical safety accepted.

The study continues with the deduction of expressions for the unitary shear forces and for the total bending unitary moments, dependent on the loads $Q_{03}$ and $M_{03}$, as indicated for in paper [12]. The integral bending unitary moment $M_{\mathrm{c}}(x)$ is entered in the formulas used for the calculation of the longitudinal stress $\sigma_{1}(x)$ and the circumferential stress $\sigma_{2}(x)$, resulting in the forms:

$$
\begin{gathered}
\sigma_{1}(x)=\frac{p_{i} \cdot D_{m c}}{4 \cdot \delta} \pm \frac{6 \cdot M_{c}(x)}{\delta^{2}}+E_{c} \cdot \alpha_{c} \cdot \Delta T_{c} \\
\sigma_{2}(x)=\frac{p_{i} \cdot D_{m c}}{2 \cdot \delta} \pm \frac{6 \cdot \mu_{c} \cdot M_{c}(x)}{\delta^{2}}+E_{c} \cdot \alpha_{c} \cdot \Delta T_{c} .
\end{gathered}
$$

Deterioration and residual stresses

The deterioration of weldements due to flaws or cracks, as well as the residual stresses in the heat affected zone may reduce the strength of the flange joint.

As to take into consideration the:

- deterioration and the residual stresses one calculates the critical stress, $\sigma_{c r}$, with the relations proposed in the papers [60-64];

- superposition of different loads one may use the results reported in the papers [65-71];

- fatigue of flanges joint due to pressure or/and temperature fluctuations is useful to consider the relationships proposed in the papers [72-76].

Abbreviations

$D_{i}$ - inside diameter of cylindrical shell, $\mathrm{mm} ; D_{e c}=D_{i c}+2 \cdot \delta$ - outside diameter of the cylindrical shell, mm; $D_{m c}=D_{i c}+\delta$ - mean diameter of the cylindrical shell, mm; $D_{i g}$ - inside diameter of the gasket (not deformed) for sealing, mm; $D_{e g}$ - outside diameter of the gasket (not deformed) for sealing, $\mathrm{mm} ; D_{m g}=0.5 \cdot\left(D_{i g}+D_{e g}\right)$ - mean diameter of the gasket load reaction (not deformed) for sealing, $\mathrm{mm} ; D_{e f}$ - outside diameter of flange ring, mm; $D_{i f}$ - inside diameter of flange ring, $\mathrm{mm} ; D_{b}$ - the bolt circle diameter, $\mathrm{mm} ; D_{m f}=0.5 \cdot\left(D_{i f}+D_{e f}\right)$ - the mean diameter of the flange ring, $\mathrm{mm}$; when considering the effect of bolt holes the value of this diameter is corrected accordingly [21, 22], $E_{c}, E_{f}$, $E_{g}, E_{b}$ - modulus of longitudinal elasticity of materials for cylindrical shell , flange ring, sealing gasket and bolt , N/mm ${ }^{2} ; \bar{F}_{f g}=\mu_{f g} \cdot\left(\bar{P}_{g}-\bar{P}_{2}\right)$ - unitary friction force between flange ring and sealing gasket, 
$\mathrm{N} / \mathrm{mm} ; M_{c}(x)$ - unitary bend moment developed by the $M_{03}$ bending unitary moments and unitary shear forces $Q_{03}$ along the $x$ dimension [12,22]; $M_{0 k}$ - bending unitary moments $(\mathrm{k}=1,2,3), \mathrm{N} \cdot \mathrm{mm} / \mathrm{mm} ; P_{1}$ - the total axial force developed by the internal pressure at operating conditions or by the hydraulic test pressure, $\mathrm{N} ; \bar{P}_{1}$ - axial unitary force developed by force $P_{1}, \mathrm{~N} / \mathrm{mm} ; P_{2}$ - the total axial force developed by the internal pressure at operating conditions or by the hydraulic test pressure, on the annular surface between the outside diameter of the cylindrical shell and the mean diameter of the undeformed gasket, $\mathrm{N} ; \bar{P}_{2}$ - axial unitary force developed by force $P_{2}, \mathrm{~N} / \mathrm{mm} ; P_{g}$ - total axial force developed by tightening pressure of sealing gasket, $\mathrm{N} ; \bar{P}_{g}=P_{2} \cdot\left(\pi \cdot D_{m g}\right)$ - axial unitary force developed by tightening pressure of sealing gasket, $\mathrm{N} / \mathrm{mm} ; P_{b}$ - the force developed in bolted flange assembly under different operating conditions $[10,18] ; \bar{P}_{b}=P_{b} \cdot\left(\pi \cdot D_{b}\right)$ - the unitary force existing on the circumference of the diameter $D_{b} ; Q_{0 k}$ - unitary shear forces, of connection $(k=1,2,3), \mathrm{N} / \mathrm{mm} ; c_{g}$ - the "reduction" coefficient of the initial gasket width, which can be chosen considering recommendations from the literature; $c_{\vartheta}^{g}, c_{\vartheta}^{b}, c_{\vartheta}^{f g}$ - selection factors used to store (accepting the value equal to the unit) or eliminate the influence of gasket rotation, bolt rotation, respectively the friction between gasket and flange ring (accepting the value equal to zero); $d_{b}$ - nominal diameter of the bolt, mm; $f_{1 m}, f_{2 m}, f_{m d}\left(h_{c}\right), f_{m r}\left(h_{c}\right), f_{1 q}, f_{23 q}, f_{q d}\left(h_{c}\right), f_{q r}\left(h_{c}\right)$ - factors of influence of the connecting loads (unitary shear forces and bending unitary moments); $h_{c}$ the length of the cylindrical shell fixed by welding on the flange ring, $\mathrm{mm} ; h_{f}$ - the flange ring thickness, $\mathrm{mm} ; h_{g}$ - gasket thickness, $\mathrm{mm} ; k_{c}$ - attenuation factor of the contour effect, $\mathrm{mm}^{-1} ; k_{g b}$ - the influence factor, with meaning of force, of the elements that can diminish the value of the rotation of the flange ring under the action of the loads given by the internal pressure and the connecting loads, i.e. the eccentric compression of the sealing gasket, the tendency to rotate the bolts and the friction between gasket and the flange ring, $\mathrm{N} ; k_{w f}$ - influence factor on the width of the flange ring of the shear unitary forces (of connecting), $\mathrm{mm}^{2} / \mathrm{N} ; k_{\vartheta b}$ - coefficient which takes into account the "resistance" opposed to the rotation tendency of the bolts, the eccentric compression of the gasket for sealing, respectively the friction between the gasket and the flange ring; $l_{b}$ - calculation length of bolts, $\mathrm{mm}$; $l_{s c}$ - half-wave length, $\mathrm{mm}[9,15] ; m_{g}, m_{b}$ - bending unitary moments, developed by eccentric compression of the gasket and tendency of bolt bending, $\mathrm{N} \cdot \mathrm{mm} / \mathrm{mm} ; n_{b}$ - number of bolts of flange assembly; $p_{i}$ - over internal pressure or of the hydraulic / pneumatic test, $\mathrm{N} / \mathrm{mm}^{2} ; p_{g}$ - the compression pressure of the gasket (assembly condition), $\mathrm{N} / \mathrm{mm}^{2} ; \mathfrak{R}_{c}$ - cylindrical bending stiffness of pressure vessel, $\mathrm{N} \cdot \mathrm{mm} ; \Delta T_{c}, \Delta T_{f}$ - the thermal gradient of the cylindrical shell, relative to the ambient temperature, respectively, the thermal gradient of the flange ring at the interior surface of the flange, $\mathrm{K} ; \Delta R\left(\Delta T_{f}\right)_{D=D_{i f}}$ - the radial displacement of the flange ring under the influence of the thermal gradient, for the accepted temperature variation law [77]; $\delta$ - thickness of cylindrical shell, $\mathrm{mm} ; \alpha_{c}, \alpha_{f}$ - the thermal deformation factor for the cylindrical shell and the flange ring, $\mathrm{K}^{-1} ; \mu_{c}, \mu_{f}$ - the Poisson coefficient (of the transverse contraction) of the cylindrical shell material, the flange ring material; $\mu_{f g}$ - the coefficient of friction between the sealing gasket and the flange ring; note the advantage of the roughness of the contact surface of the flange ring facing with the gasket, drag lines and suitable groove to prevent eventual expulsion of the gaskets; $\vartheta_{f}$ - flange ring rotation; $\sigma_{1}(x), \sigma_{2}(x)$, - normal stress on the longitudinal and circumferential directions, respectively developed along the cylindrical shell (the size $\mathrm{x}$ being measured at the shell-to-flange intersection), $\mathrm{N} / \mathrm{mm}^{2}$.

\section{Conclusions}

The analytical study of mechanical and thermal stresses that occurs in welded ring flange attached to a cylindrical shell with full penetration welds uses the theory of compatibility between the elastic deformations produced in the component parts. In this sense the three elements of the structure are 
distinguished (Figure 2) put to use for writing the algebraic linear system, through the solving of which the expressions of the connection loads (radial unitary bending moments and unitary shear forces) are deduced.

After the eventual correction of the loading scheme, the calculation of the axial and circumferential stresses developed on the inside and outside surfaces of a cylindrical shell, along its length, is made, in order to position the plane in which the equivalent stress is maximum and obviously below the allowable stress value of material at operating conditions.

An appropriate calculation program can lead to optimized construction, under conditions that are acceptable for minimizing material consumption, under the conditions required for safe operation.

\section{Appendix}

The function that helps calculate the rotation of the flange ring, having in its composition influenced by the connection loads and external loads:

$$
\begin{aligned}
& f\left(Q_{01}, M_{01}, Q_{02}, M_{02}, \bar{P}_{2}, \bar{P}_{b}, \bar{P}_{s}\right)=0.5 \cdot h_{f} \cdot Q_{01}-\frac{D_{i f}}{D_{m f}} \cdot M_{01}-0.5 \cdot h_{f} \cdot Q_{02}-\frac{D_{i f}}{D_{m f}} \cdot M_{02}+ \\
& +0.5 \cdot\left(D_{m f}-D_{2}\right) \cdot \bar{P}_{2}+0.5 \cdot\left(D_{b}-D_{m f}\right) \cdot \bar{P}_{b}+0.5 \cdot\left(D_{m f}-D_{2}\right) \cdot \bar{P}_{g}
\end{aligned} .
$$

The terms of the influence factors matrix, deduced through the writing of the algebraic equations containing the deformations - radial elastic displacements and rotations - written for the couples 1 - 2 and 1 - 3 (Fig. 2), deduced through the decoupling of the sizes involved, have the following forms:

$$
\begin{aligned}
& a_{11}=f_{1 q} \cdot\left(2 \cdot k_{c}^{3} \cdot \mathfrak{R}_{c}\right)^{-1}-k_{w f}-h_{f}^{2} \cdot\left(4 \cdot k_{g b}\right)^{-1} ; \\
& a_{12}=f_{1 m} \cdot\left(2 \cdot k_{c}^{2} \cdot \mathfrak{R}_{c}\right)^{-1}+h_{f}^{2} \cdot D_{i f} \cdot\left(D_{m g} \cdot k_{b}\right)^{-1} ; \\
& a_{13}=f_{q d}\left(h_{c}\right) \cdot\left(2 \cdot k_{c}^{3} \cdot \mathfrak{R}_{c}\right)^{-1}-k_{w f}+h_{f}^{2} \cdot\left(4 \cdot k_{g b}\right)^{-1} ; \\
& a_{14}=-f_{m d}\left(h_{c}\right) \cdot\left(2 \cdot k_{c}^{2} \cdot \mathfrak{R}_{c}\right)^{-1}-h_{f} \cdot D_{i f} \cdot\left(2 \cdot D_{m f} \cdot k_{g b}\right)^{-1} ; \\
& a_{15}=f_{q d}\left(h_{c}\right) \cdot\left(2 \cdot k_{c}^{3} \cdot \mathfrak{R}_{c}\right)^{-1} ; \\
& a_{16}=-f_{m d}\left(h_{c}\right) \cdot\left(2 \cdot k_{c}^{2} \cdot \mathfrak{R}_{c}\right)^{-1} ; \\
& a_{21}=-f_{23 q} \cdot\left(2 \cdot k_{c} \cdot \mathfrak{R}_{c}\right)^{-1}-0.5 \cdot h_{f} \cdot\left(k_{g b}\right)^{-1} ; \\
& a_{22}=f_{2 m} \cdot\left(k_{c} \cdot \mathfrak{R}_{c}\right)^{-1}+D_{i f} \cdot\left(D_{m g} \cdot k_{g b}\right)^{-1} ; \\
& a_{23}=f_{q r}\left(h_{c}\right) \cdot\left(2 \cdot k_{c}^{3} \cdot \mathfrak{R}_{c}\right)^{-1}+0.5 \cdot h_{f} \cdot\left(k_{g b}\right)^{-1} ; \\
& a_{24}=f_{m r}\left(h_{c}\right)-D_{i f} \cdot\left(D_{m f} \cdot k_{g s}\right)^{-1} ; \\
& a_{25}=f_{q r}\left(h_{c}\right) \cdot\left(2 \cdot k_{c}^{2} \cdot \mathfrak{R}_{c}\right)^{-1} ; \\
& a_{26}=f_{m r}\left(h_{c}\right) \cdot\left(2 \cdot k_{c} \cdot \mathfrak{R}_{c}\right)^{-1} ; \\
& a_{31}=f_{q d}\left(h_{c}\right) \cdot\left(2 \cdot k_{c}^{3} \cdot \mathfrak{R}_{c}\right)^{-1}-k_{w f}+h_{f}^{2} \cdot\left(4 \cdot k_{g b}\right)^{-1} ; \\
& a_{32}=f_{m d}\left(h_{c}\right) \cdot\left(2 \cdot k_{c}^{2} \cdot \mathfrak{R}_{c}\right)^{-1}-0.5 \cdot h_{f} \cdot D_{i f} \cdot\left(D_{m g} \cdot k_{g b}\right)^{-1} ; \\
& a_{33}=f_{1 q} \cdot\left(2 \cdot k_{c}^{3} \cdot \mathfrak{R}_{c}\right)^{-1}-k_{w f}-h_{f}^{2} \cdot\left(4 \cdot k_{g b}\right)^{-1} ;
\end{aligned}
$$




$$
\begin{aligned}
& a_{34}=f_{1 m} \cdot\left(2 \cdot k_{c}^{2} \cdot \Re_{c}\right)^{-1}+0.5 \cdot h_{f} \cdot D_{i f} \cdot\left(D_{m g} \cdot k_{g b}\right)^{-1} \text {; } \\
& a_{35}=f_{1 q} \cdot\left(2 \cdot k_{c}^{3} \cdot \Re_{c}\right)^{-1} \text {; } \\
& a_{36}=f_{1 m} \cdot\left(2 \cdot k_{c}^{2} \cdot \mathfrak{R}_{c}\right)^{-1} \text {; } \\
& a_{41}=-f_{q r}\left(h_{c}\right) \cdot\left(2 \cdot k_{c}^{2} \cdot \Re_{c}\right)^{-1}-0.5 \cdot h_{f} \cdot\left(k_{g b}\right)^{-1} \text {; } \\
& a_{42}=-f_{m r}\left(h_{c}\right) \cdot\left(2 \cdot k_{c} \cdot \Re_{c}\right)^{-1}+h_{f} \cdot D_{i f} \cdot\left(D_{m g} \cdot k_{g b}\right)^{-1} \text {; } \\
& a_{43}=f_{23 q} \cdot\left(2 \cdot k_{c}^{2} \cdot \Re_{c}\right)^{-1}+0.5 \cdot h_{f} \cdot\left(k_{g b}\right)^{-1} \text {; } \\
& a_{44}=-f_{2 m} \cdot\left(k_{c} \cdot \Re_{c}\right)^{-1}-D_{i f} \cdot\left(D_{m f} \cdot k_{g b}\right)^{-1} \text {; } \\
& a_{45}=f_{23 q} \cdot\left(2 \cdot k_{c}^{2} \cdot \Re_{c}\right)^{-1} \text {; } \\
& a_{46}=-f_{2 m} \cdot\left(k_{c} \cdot \Re_{c}\right)^{-1} \text {; } \\
& a_{51}=f_{q d}\left(h_{c}\right) \cdot\left(2 \cdot k_{c}^{3} \cdot \mathfrak{R}_{c}\right)^{-1} \text {; } \\
& a_{52}=f_{m d}\left(h_{c}\right) \cdot\left(2 \cdot k_{c}^{2} \cdot \mathfrak{R}_{c}\right)^{-1} \text {; } \\
& a_{53}=f_{1 q} \cdot\left(2 \cdot k_{c}^{3} \cdot \Re_{c}\right)^{-1} \text {; } \\
& a_{54}=f_{1 m} \cdot\left(2 \cdot k_{c}^{2} \cdot \mathfrak{R}_{c}\right)^{-1} \text {; } \\
& a_{55}=\left(f_{1 q}-1\right) \cdot\left(2 \cdot k_{c}^{3} \cdot \mathfrak{R}_{c}\right)^{-1} \text {; } \\
& a_{56}=\left(f_{1 m}-1\right) \cdot\left(2 \cdot k_{c}^{2} \cdot \mathfrak{R}_{c}\right)^{-1} \text {; } \\
& a_{61}=f_{q r}\left(h_{c}\right) \cdot\left(2 \cdot k_{c}^{2} \cdot \mathfrak{R}_{c}\right)^{-1} \text {; } \\
& a_{62}=f_{m r}\left(h_{c}\right) \cdot\left(2 \cdot k_{c} \cdot \mathfrak{R}_{c}\right)^{-1} \text {; } \\
& a_{63}=-f_{23 q} \cdot\left(2 \cdot k_{c}^{2} \cdot \Re_{c}\right)^{-1} \text {; } \\
& a_{64}=f_{2 m} \cdot\left(k_{c} \cdot \Re_{c}\right)^{-1} \text {; } \\
& a_{65}=\left(1-f_{23 q}\right) \cdot\left(2 \cdot k_{c}^{2} \cdot \mathfrak{R}_{c}\right)^{-1} \text {; } \\
& a_{66}=\left(1+f_{2 m}\right) \cdot\left(2 \cdot k_{c} \cdot \Re_{c}\right)^{-1} \text {. }
\end{aligned}
$$

The terms of the radial displacements vector and the particular rotations caused by the internal pressure and temperature, existing in the structure of the deformations congruence equations, are represented by the configurations:

$$
\begin{aligned}
& b_{1}=\left\lfloor p /\left(8 \cdot k_{c}^{2} \cdot \Re_{c}\right)\right] \cdot\left[2-\mu_{c} \cdot D_{i}^{2} / D_{m c}^{2}\right\rfloor+0.5 \cdot \alpha_{c} \cdot D_{m c} \cdot \Delta T_{c}+ \\
& +h_{f} \cdot\left(4 \cdot k_{g b}\right)^{-1} \cdot\left[\begin{array}{l}
\left(D_{m g}-D_{2}+\mu_{f g} \cdot h_{f} \cdot c_{\vartheta}^{f g}\right) \cdot \bar{P}_{2}+\left(D_{b}-D_{m f}\right) \cdot \bar{P}_{b}+ \\
+\left(D_{m f}-D_{m g}-\mu_{f g} \cdot h_{f} \cdot c_{\vartheta}^{f g}\right) \cdot \bar{P}_{g}
\end{array}\right]-\Delta R\left(\Delta T_{f}\right)_{D=D_{i f}}
\end{aligned} ;
$$




$$
\begin{aligned}
& b_{2}=\left(2 \cdot k_{g b}\right)^{-1} \cdot\left(\left[D_{m g}-D_{2}+\mu_{f g} \cdot h_{f} \cdot c_{\vartheta}^{f g}\right) \cdot \bar{P}_{2}+\left(D_{b}-D_{m f}\right) \cdot \bar{P}_{b}+\left(D_{m f}-D_{m g}-\mu_{f g} \cdot h_{f} \cdot c_{\vartheta}^{f g}\right) \cdot \bar{P}_{g}\right] \\
& b_{3}=\left\lfloor p /\left(8 \cdot k_{c}^{4} \cdot \mathfrak{R}_{c}\right)\right] \cdot\left[\begin{array}{l}
\left.2-\mu_{c} \cdot D_{i}^{2} / D_{m c}^{2}\right\rfloor+0.5 \cdot \alpha_{c} \cdot D_{m c} \cdot \Delta T_{c}- \\
-h_{f} \cdot\left(4 \cdot k_{g b}\right)^{-1} \cdot\left[\begin{array}{l}
\left.\left(D_{m g}-D_{2}+\mu_{f g} \cdot h_{f} \cdot c_{\vartheta}^{f g}\right) \cdot \bar{P}_{2}+\left(D_{b}-D_{m f}\right) \cdot \bar{P}_{b}+\right] \\
+\left(D_{m f}-D_{m g}-\mu_{f g} \cdot h_{f} \cdot c_{\vartheta}^{f g}\right) \cdot \bar{P}_{g}
\end{array}\right]-\Delta R\left(\Delta T_{f}\right)_{D=D_{i f}} \\
b_{4}=b_{2}=\left(2 \cdot k_{g b}\right)^{-1} \cdot\left(\left(D_{m g}-D_{2}+\mu_{f g} \cdot h_{f} \cdot c_{\vartheta}^{f g}\right) \cdot \bar{P}_{2}+\left(D_{b}-D_{m f}\right) \cdot \bar{P}_{b}+\left(D_{m f}-D_{m g}-\mu_{f g} \cdot h_{f} \cdot c_{\vartheta}^{f g}\right) \cdot \bar{P}_{g}\right.
\end{array}\right] \\
& b_{5}=b_{6}=0,
\end{aligned}
$$

in which help sizes intervene:

$$
\begin{aligned}
& P_{1}= 0.25 \cdot \pi \cdot D_{e c}^{2} \cdot p_{i} ; \\
& \bar{P}_{1}= P_{1} /\left(\pi \cdot D_{m c}\right) ; \\
& P_{2}= 0.25 \cdot \pi \cdot\left(D_{m g}^{2}-D_{e c}^{2}\right) \cdot p_{i} ; \\
& \bar{P}_{2}= 0.5 \cdot \pi \cdot\left(D_{m g}-D_{e c}\right) \cdot p_{i} ; \\
& P_{g}= 0.25 \cdot \pi \cdot\left(D_{e g}^{2}-D_{i g}^{2}\right) \cdot p_{g} ; \\
& \bar{P}_{g}= 0.5 \cdot \pi \cdot\left(D_{e g}-D_{i g}\right) \cdot p_{g} ; \\
& \mathfrak{R}_{c}= \frac{E_{c} \cdot \delta^{3}}{\sqrt{12 \cdot\left(1-\mu_{c}^{2}\right)}} \\
& k_{c}= \frac{4}{12 \cdot\left(1-\mu_{c}^{2}\right)} \\
& \sqrt{D_{m c} \cdot \delta} ; \\
& k_{w f}= \frac{D_{i f} \cdot h_{f} \cdot E_{f} \cdot\left(D_{e f}^{2}-D_{i f}^{2}\right)}{\left[\left(1-\mu_{f}\right) \cdot D_{e f}^{2}-\left(1-2 \cdot \mu_{f}\right) \cdot D_{i f}^{2}\right] ;} \\
& k_{g b}= \frac{E_{f} \cdot h_{f}^{3} \cdot \ln \left(D_{e f} / D_{i f}\right)}{6 \cdot D_{m g}}+\frac{D_{m g}}{D_{m f}} \cdot \frac{E_{g} \cdot c_{g}^{3} \cdot\left(D_{e g}-D_{i g}\right)^{3}}{48 \cdot h_{g}} \cdot c_{\vartheta}^{g}+\frac{D_{b}}{D_{m f}} \cdot \frac{E_{b} \cdot n_{b} \cdot d_{b}^{4} \cdot k_{\vartheta}^{b}}{16 \cdot l_{b} \cdot D_{b}} \cdot c_{\vartheta}^{b}+ \\
&+0.5 \cdot h_{f} \cdot \mu_{f g} \cdot\left(\bar{P}_{g}-\bar{P}_{2}\right) \cdot c_{\vartheta}^{f g}
\end{aligned}
$$

\section{References}

1. IATAN I.R., BEZMAN, I.V., Aspecte privind solicitarea termo-mecanica a suruburilor de chiulasa ale motoarelor termice, SINUC 2007 - Sect. a II-a, Univ. Tehnica de Constructii Bucuresti, 2007, p. 5061.

2. IATAN, I.R., Consideratii teoretice privind etanseitatea chiulaselor motoarelor cu ardere interna, SINUC 2010 - Sect. a II-a, Univ. Tehnica de Constructii Bucuresti, 2010, p. 24-37.

3. BEZMAN, I.V., Cercetari privind comportarea la soc termic a garniturilor de chiulasa ale motoarelor cu ardere interna, Teza de doctorat, Univ. Politehnica din Bucuresti, 2000.

4. $\quad * * *$ ASME Boiler and Pressure Vessel Code. Section VIII, Division 2, Rules for construction of pressure vessels, 2010.

5. $\quad * * *$ British Standard PD - 5500, Specification for fusion welded pressure vessels, 2009.

6. $\quad * * *$ European Standard 13445, Unfired pressure vessels - Part 3: Design -, 2009.

7. $* * *$ EN 1591, Flanges and their joints - Design rules for gasketed circular flange connections - Part 
1: Calculation method, 2014.

8. RENERT, M., Calculul si constructia utilajului chimic, vol. 1, Ed. Didactica si Pedagogica, Bucuresti, 1971.

9. JINESCU, V.V., Utilaj tehnologic pentru industrii de proces, vol. 3, Ed. Tehnica, Bucuresti, 1988. 10. KOPTEVA, V.B., KOPTEV, A.A., Flantevâe soedineniia: konstruktii, razmeri, rascet na procinosti, Izd. FGBOI VPO, „TGTU”, 2011.

11. JINESCU, V.V., TEODORESCU, N., Metoda pentru calculul asamblarilor cu flanse, Constr. de Masini, 52, no. 12, 2000, p. 1-8.

12. JINESCU, V.V., Calculul si constructia utilajului chimic, petrochimic și de rafinarii, vol. 1, Ed. Tehnica, Bucuresti, 1983.

13. JINESCU, V.V., TEODORESCU, N., Constructia si calculul imbinarilor cu flanse (I), Rev. Chim., 32, (3), 1981, 286

14. JINESCU, V.V., TEODORESCU, N., Constructia si calculul imbinarilor cu flanse (II), Rev. Chim., 32, (4), 1981, 385

15. JINESCU, V.V., TEODORESCU, N., Constructia si calculul imbinarilor cu flanse (III), Rev. Chim., 33, (7), 1982, 671

16. JINESCU, V.V., TEODORESCU, N., GARDUS, V., Constructia si calculul imbinarilor cu flanse (IV), Rev. Chim., 38, (8), 1987,727

17. JINESCU, V.V., TEODORESCU, N., GARDUS, V., Calculul si constructia asamblarilor cu flanse (V), Rev. Chim., 39, no. 1, 1988, 75-77.

18. JINESCU, V.V., TEODORESCU, N., GARDUS, V. (VI), Calculul si constructia asamblarilor cu flanse, VI, Rev. Chim., 39, no. 2, 1988, p. 185-188.

19. JINESCU, V. V., URSE, G., CHELU, A., Evaluation and completion the design methods of pressure vessels flange joints, Rev. Chim., 69, (8), 2018, 1954

20. URSE G., DURBACA I., PANAIT I.C., Some research results on the tightness and strength of flange joints, J. Eng. Sciences and Innovation, 3, no. 2, 2018, p. 107-130.

21. IATAN, I.R., Consideratii asupra calculului flanselor inelare sudate, in faza de montaj, I. P.B. Sci. Bull., Series D, Vol. 53, 1981, p. 101-112.

22. IATAN, I.R., Contributii la calculul mecanic al imbinarilor cu flanse plate inelare, sudate, I. P.B. Sci. Bull., Series D, Vol. 53, 1983, p. 50-60.

23. IATAN, I.R., ALAMOREANU, E., IORDAN, N., CHIRITA, R., Calculus elements for ring neck flanges, MOCM 3, University of Bacau, 1997, p. 14-17.

24. IATAN, I.R., RENERT, M., Calculul si constructia flanselor cu nervuri, I. P.B. Sci. Bull., Series D, Vol. XI, 1978, no. 2, p. 51-60.

25. IATAN I.R., RENERT M., BOTEA N., Metoda de calcul pentru flansele cu nervuri tesite, Rev. Chim., 29, (7), 1978, 678

26. IATAN, I. R., RENERT, M., Stari de deformatii si de eforturi unitare in inelele flanselor cu nervuri, Rev. Chim., 32, (5), 1981, 491

27. IATAN, I.R., RENERT, M., Cercetari experimentale privind solicitarea prezoanelor imbinarilor cu flanse cu nervuri, I. P.B. Sci. Bull., Series D, Vol. 53, no. 3, 1981, p. 95-102.

28. IATAN, I.R., Cercetari teoretice si experimentale privind constructiile de imbinari cu flanse cu nervuri, Teza de doctorat, Inst. Politehnic din Bucuresti, 1979.

29. BURSI, S.O., ROZA, S.M., KUMAR, A., PAOLACCI, F., Seismic performance of bolted flange joints in piping systems for oil gas industries, Proceedings 15WCEE, Lisbon, Portugal, 2012.

30. NASH, H. D., ABID, M., Combined external load tests for standard and compact flanges, Int. J. Press. Vessels and Piping, 77 (13), 2000, p. 799-806.

31. TEODORESCU, ST., VOICU, I., Calculul solicitarilor din imbinarile demontabile cu flanse, Rev. Chim., 34, (1), 1983, 57

32. PAMFIL, V., Calculul si optimizarea asamblarilor prin flanse, Rev. Chim., 35, (2), 1984, p. 152 
33. JINESCU, V.V., IORDACHESCU, V.I., TEODORESCU, N., Relation for Calculation of Critical Stresses in Pressure Equipment with Cracks, Rev. Chim., 64, (8), 2013, 858

34. JINESCU, V.V., MANEA, S.E., JINESCU, C., The result of loads superposition upon the matter and particularity upon the environment, Rev. Chim., 68, (4), 2017, 656

35. JINESCU, V.V., NICOLOF, V.I., JINESCU, C., CHELU, A., Superposition of Effects in Calculating the Deterioration of Tubular Structures and in Non-newtonian Fluid Flow, Rev. Chim. (Bucharest), 66, (5), 2015, 698

36. JINESCU, V.V., CHELU, A., TEODORESCU, N., NICOLOF, V.I., Strength of tubular samples and tubular cracked junctions under combined loads, Rev. Chim., 66, (11), 2015, 1832

37. MOGLO, E.K., Etude des brides boulonnées en materiaux composites, These, Université de Montréal, 1996.

38. IATAN, I.R., RENERT, M., Cercetari experimentale privind starea de tensiuni in zona cilindrica a constructiilor cu flanse cu nervuri, Studii si Cercetari de Mecanica Aplicata, 44, no. 4, 1985, p. 384 395.

39. IATAN, I.R., FILIMON, C., Calculul asamblarilor cu flanse si cleme, Rev. Chim., 42, (1-3), 1991, 117

40. IATAN, I.R., FILIMON, C., Calculul asamblarilor cu flanse si cleme, II, Rev. Chim., 42, (8-9), 1991,443

41. IORDACHE, Gh., IATAN, I.R., NUCA, G., Calculul agrafelor simple, utilizate la imbinarea cu flanse a recipientelor sub presiune, Constr. de Masini, 29, no. 1, 1977, p. 33-39.

42. COUCHAUX, M., RYAN, I., HJIAJ, M., Stress concentration factor for the fatigue design of tubular flange connections, NSCC, 2009, p. 255-262.

43. JINESCU, V.V., PAUNESCU, M., Etanseitatea asamblarilor cu flanse, Rev. Chim. (Bucharest), 41, no. (11-12), 1990, 898

44. PAUNESCU, M., MANOLACHE, Z., TACA, C. D., Studiul experimental al asamblarilor cu flanse plate cu garnituri din marsit, I. P.B. Sci. Bull., Constr. de Masini, Vol. XLIX, 1987, p. 83-88.

45. PAUNESCU, M., Rigiditatea asamblarilor cu flanse ale recipientelor sub presiune, Constr. de masini, 53, no. 4, 2001, p. 9-13.

46. TACA, C.D., PAUNESCU, M., Influenta deformatiei circumferentiare a inelului flansei plate asupra etanseitatii, I. P.B. Sci. Bull., Seria Mecanica, Vol. L, 1988, p. 91-96.

47. PAUNESCU, M., TACA, C.D., STEFANESCU, M.F., Flanged joints rigidity of the pressure vessels, Romanian Academy, MOCM-6, 2000, p. 45-51.

48. IATAN, I.R., ROMAN, G., Considerations about flange with ring gasket. The sealing pressure, Rev. Chim., 60, (11), 2009, 119

49. TOMESCU, Gh., IATAN, I. R., Criterii de alegere a materialelor fara azbest pentru etansari statice, Constr. de Masini, 55, no. 7-8, 2003, p. 78-81.

50. DO, D. T., The effect of bolt spacing on the tightness behavior of bolted flange joints, Thèse, École de Technologie Superieure, Univ. du Québec, 2012.

51. KURZ, H., Auslegung und optimierung von flanschverbindungen mit SMC - Losflanschen und PTFE - dichtungen, Dissertation, Univ. Stuttgart, 2014.

52. DIANY, M., Determination de la largeur effective des joints d'etancheite utilisee dans le Code ASME pour le calcul des brides, These, Ecole de Technologie Supérieure, Univ. du Quebec, 2005.

53. PAUNESCU, M., Experimental research regarding gaskets durability, Int. J. Fatigue, 28, 2006, p. 1081-1086.

54. PAUNESCU, M., Behaviour of non-metallic gaskets in small and medium pressure conditions, Rev. Chim., 61, (2), 2010. 118

55. RENERT, M., POPA, A., Probleme de proiectare a imbinarilor cu flanse, B. I. T. in tehnica supravegherii instalatiilor mecanice sub presiune si de ridicat, no. 2, 1972, p. 116-123.

56. BOUZID, A. H., BEGHOUL, H., A New Proposed Method For The Design Of Bolted Joints 
Based On Flexibility And Tightness, Proceedings ICPVT - 10, Austria ,2003, p. 293-301.

57. GALAI, H., Analyse des assemblages a brides boulonnées a face plate, These, Ecole de Technologie Superieure, Univ. du Quebec, 2009.

58. SCHMUCKING, R., Zum kreichverhalten der dichtung in einer flanschverbindungen, Wissenschaftliche Zeitschrift der Technischen Hochschule Otto von Guericke, Magdeburg, 14, no. 8, 1970, p. 967-975.

59. LUYT, B. C. P., A leak tight design methodology for large diameter flanges based on non - linear modelling and analysis, Thesis, Dep. Mech. and Aeronautical Eng., Univ. of Pretoria, 2015.

60. JINESCU, V.V., IORDACHESCU, V. I., TEODORESCU, N., Relations for the calculation of critical stress in pressure equipments with cracks, Rev. Chim., 54, (8), 2013, 858

61. JINESCU, V.V., Prediction of the influence of Residual Stresses to Strength and Lifetime of Process Equipment, Rev. Chim., 60, (11), 2009, 114

62. JINESCU, V.V., Tratat de termomecanica, vol. 1, Ed. AGIR, Bucuresti, 2011.

63. JINESCU, V.V., JINESCU, G., Durata de viata a structurilor tehnice si a organismelor vii, Ed. Tehnica-Info, Chisinau, 2018.

64. JINESCU, V.V., NICOLOF, V.I., CHELU, A., MANEA, S.E., Calculation of the local critical state taking into account the deterioration and the residual stresses, J. Eng. Sciences and Innovation, 2, no. 3, 2017, p. 9-21.

65. JINESCU, V.V., CHELU, A., ZECHERU, GH., PUPAZESCU, AL., SIMA, T., DRAGHICI, GH., The influence of loads superposition, deterioration due to cracks and residual stresses on the strength of tubular junction, Rev. Chim., 68, (6), 2017, 1365

66. JINESCU, V.V., MANEA, S.E., JINESCU, C., The result of loads superposition upon the matter and particularity upon the environment, Rev. Chim., 68, (4), 2017, 656

67. JINESCU, V.V., TEODORESCU, N., JINESCU, G., PANAIT, I.C., The result superposition of different actions upon the mechanical structures and living organisms, Rev. Chim., (67), no. 12, 2016, 2607

68. JINESCU, V.V., CHELU, A., TEODORESCU, N., NICOLOF, V.I., Strength of tubular samples and tubular cracked junctions under combined loads, Rev. Chim., 66, (11), 2015, 1832

69. JINESCU, V.V., NICOLOF V.I., JINESCU, C., CHELU, A., Superposition of Effects in Calculating the Deterioration of Tubular Structures and in Non-newtonian Fluid Flow, Rev. Chim., 66, (5), 2015, p. 698

70. JINESCU, V. V., Energonica, Ed. Semne, Bucuresti, 1997.

71. JINESCU, V. V., Energia, Energonica si Termodinamica, Ed. AGIR, Bucuresti, 2016.

72. JINESCU, V.V., Fatigue life prediction for simultaneous cyclic loading with blocks of normal stresses and shear stresses, J. Eng. Sciences and Innovation, 1, no. 1, 2016, p. 1-16.

73. JINESCU, V.V., Critical Energy Approach for the Fatigue life Calculation under Blocks with different normal Stress Amplitudes, Int. J. Mechanical Sci., 67, 2013, p. 78-88.

74. JINESCU, V.V., Cumulation of Effects in calculation the Deterioration of Fatigue loaded Structures, Int. J. Damage Mechanics, 21, 2012, p. 671-695.

75. JINESCU, V.V., Applications in mechanical engineering of the principle of critical energy, Saarbrucken, Ed. Lambert Academic, 2015.

76. JINESCU, V.V., Fatigue Life of the Process Equipment Made of Nonlinear Materials, Rev. Chim., 63, (1), 2012, 98

77. IATAN, I. R., Placi circulare si inelare, gofrate si perforate, Ed. Matrix Rom, Bucuresti, 2012.

Manuscript received: 6.07 .2019 